\title{
Beatings, Burnings, and Bombings: Disaggregating Ethnic Violence in Egypt, 2013-2018
}

\author{
Christopher Barrie, Killian Clarke, and Neil Ketchley*
}

May 4, 2020

\begin{abstract}
What are the drivers of ethnic violence? Existing research posits an array of explanations: from economic strain to political mobilization and state capacity. This diversity of accounts is attributable to scholars' tendency to lump together different forms of ethnic violence. Analyzing anti-Christian violence in Egypt, we identify three types of event - beatings, burnings, and bombings. This typology distinguishes between the target of the attack and the level of violence. Beatings (unarmed attacks targeting individuals) are more likely where Christians are numerous, during economic downturns, and are patterned by religious calendars. Burnings (unarmed attacks targeting property) follow a political logic, occurring where Islamists are mobilizing, and following crackdowns. Beatings and burnings are more prevalent where the state's coercive capacity is diminished. Bombings (armed attacks) follow a strategic logic and are patterned by previous violence and Muslim religious holidays. Disaggregation, we suggest, can reconcile competing findings in the ethnic violence literature.
\end{abstract}

${ }^{*}$ An early version of this paper was presented at the 2019 Annual Meeting of the Midwest Political Science Association. Christopher Barrie (christopher.barrie@nuffield.ox.ac.uk) is Postdoctoral Prize Research Fellow in Sociology at Nuffield College, University of Oxford. Killian Clarke (kbclarke@princeton.edu) is a Doctoral Candidate in the Department of Politics at Princeton University. Neil Ketchley (neil.ketchley@stv.uio.no) is Associate Professor of Political Science in the Department of Political Science, University of Oslo. 


\section{Introduction}

On November 17, 2016, in a village outside of the Upper Egyptian city of Minya, a Coptic man, Talaat Beshay Gad al-Rab, was attacked by a small group of Muslim residents. His 25-year-old son, Shenouda, was allegedly having a relationship with a young Muslim woman in the village, and had been accused by the woman's family of kidnapping her. Even though she denied that she had been kidnapped and a local court had acquitted the son of any wrongdoing, the woman's family members and friends had set out to avenge the supposed affront by attacking Shenouda's father. Three years earlier, Minya had been the site of a spate of attacks on Christian churches and other properties. On August 14, 2013 members of the Muslim Brotherhood and other Islamist political movements began marching from the city's main square chanting slurs and epithets against Christians, who they accused of supporting the recent military coup against the Islamist president Mohamed Morsi. The marchers made their way to some of the city's most prominent Christian sites, which they attacked with clubs and stones, looted, and ultimately set ablaze. Then, in May 2017, on a desert road northwest of Minya, gunmen ambushed a convoy of Christian pilgrims headed to a monastery. One of the vehicles was a mini-bus of children, which the attackers sprayed with bullets. They then entered one of the buses, stole the money and jewelry from the women, and shot the men. In total, they killed 28 Christians. They left a number of jihadi leaflets strewn over the bodies, and the next day the Egyptian franchise of the Islamic State claimed credit for the attack.

The commonalities between these three events are clear: all were violent acts targeting Egypt's substantial Christian minority community. But the attacks also evince several meaningful differences. The first event was a physical attack seeking retribution against a single individual for a perceived affront to cultural mores regarding inter-faith sexual relations. The second event was a politically-motivated pogrom by local Islamists seeking to inflict collective punishment against the entire Christian community by targeting their properties and places of worship. The third event was a pre-planned attack executed by a well-organized and heavily armed transnational terrorist group. While all three events clearly fall under the category of ethnic violence, in this paper we argue that the 
differences in their characteristics are analytically important, and have too often been overlooked by scholars of ethnic politics.

Specifically, we argue that effectively analyzing the causes of ethnic violence requires disaggregating the phenomenon into its diverse forms, each of which may have its own distinct drivers. In fact, we believe that the range of arguments and explanations in the literature on ethnic violence may, in part, be attributable to scholars' tendency to lump together forms of violence that in fact have different causes. We suggest disaggregating ethnic violence into three categories, which we term beatings, burnings, and bombings, based on the nature of the target (individuals vs. properties) and the level of arms used (armed vs. unarmed). We define beatings as unarmed attacks against individuals, burnings as unarmed attacks against properties, and bombings as armed attacks against either type of target. This categorization has two advantages. First, it is substantively meaningful. By distinguishing between the target of violence we are able to capture substantive differences in the motivations for the attacks (i.e., individual retribution vs collective punishment). And by distinguishing between the levels of arms used we are able to capture substantive differences in the perpetrators' level of organization (i.e., everyday citizens with improvised weapons vs. formal organizations capable of acquiring arms). Second, the categorization is empirically tractable, in that it should be easy to apply to the coding of violent events in a diverse range of cases, even with limited information on the specifics of the attacks.

To make our case for disaggregating ethnic violence, we analyze a novel dataset of recent anti-Christian ethnic violence in Egypt, an emblematic post-colonial state in the Global South, where Coptic Christians represent roughly 10 percent of the population. Importantly, Egyptian Copts have long been persecuted both by the state and by members of Egypt's Muslim community (Brownlee 2013). ${ }^{1}$ Our dataset comprises 413 antiChristian attacks in Egypt from July 2013 to December 2018 sourced from local Arabic-

\footnotetext{
${ }^{1}$ Scholars of the Middle East sometimes distinguish between sectarian or communal identity, which is based on religion, and ethnic identity, which would refer to other characteristics (like race or language). Following the general ethnic politics literature, we consider "ethnic" all identities based on descent-based characteristics, including religion, language, and race (Horowitz 1985; Chandra 2006).
} 
and English-language websites, newspapers, human rights reports, and social media posts. Our analysis period therefore spans a number of watershed events in Egypt's recent political history, including the spate of violence following Egypt's 2013 coup and the subsequent rise of Islamist militancy in the Sinai Peninsula.

We show that this five-year period in Egypt was marked by at least three distinct types of ethnic violence: sustained low-level violence emerging from localized inter-communal tensions, attacks against religious institutions following the massacre of Morsi supporters in Cairo's Rabaa Square, and finally terrorist violence sponsored by the Islamic State's branch in the Sinai Peninsula. A statistical analysis further suggests that different subnational and temporal factors predict different types of violence. Beatings, which are retributive attacks against individual members of an ethnic group, occur where Christians are especially numerous, during periods of economic strain, and are patterned by the religious calendar, with fewer attacks on Christian holidays and more attacks on Muslim holidays. In contrast, burnings, which seek to collectively punish an ethnic community by targeting one of their symbolically important sites, are driven by more political dynamics. They, occur more frequently in districts where Islamist political organizations are mobilizing, and following episodes of government repression. Both beatings and burnings tend to cluster in districts where police officers had recently been on strike, suggesting that the state's coercive capacity is a factor in determining these types of violence. Finally, bombings, which require cohesive organizations to acquire and furnish firearms, are more strategic: they occur more often in symbolically significant city centers, follow recent episodes of anti-Christian violence, decrease on Muslim holidays, and are less obviously patterned by the distribution of the Christian population. Insofar as the Egyptian case generalizes to other contexts, our findings should alert scholars to the importance of meaningful disaggregation when studying ethnic violence. 


\section{Conflicting findings in ethnic violence studies}

Scholars of ethnic violence have proposed a range of factors that are claimed to predict its occurrence. These explanations can be grouped into three categories: those centered on the state and its coercive apparatus, those stressing social and/or economic relations, and those focused on political competition. A fourth set of explanations comes from the terrorism literature and emphasizes the strategic logics of such violence.

The first cluster of explanations focuses on the institution supposedly responsible for restraining or curtailing ethnic violence: the state and its coercive agents. In an ideal world, state coercive actors, like the police, protect ethnic minorities from predation by majority groups. But in contexts where state capacity is weak, coercive agents may lack the means (e.g., the weapons or manpower) to effectively restrain attackers. In extreme situations, for example instances of total state collapse, police forces may be entirely nonexistent, giving majority groups carte blanche to commit whatever violence they want (Petersen 2002; Kalyvas 2006). In other cases, coercive agents may lack the will to enforce order, either because of a general lack of resolve or commitment to their jobs, or because they harbor ethnic animosities of their own (Karapin 2002; Wilkinson 2004). An alternative version of the state-centered argument sees ethnic violence as a byproduct of state repression. In this understanding, ethnic violence appears as "backlash" (Francisco 2004) whereby political actors target outgroups whom they scapegoat for government crackdowns, particularly when that outgroup is (perceived to be) aligned with or backed by the government.

A second major cluster of explanations examines society-level relations between ethnic groups. An influential variant of this argument emphasizes the importance of deeplyembedded identity dynamics within episodes of ethnic violence (Horowitz 1985, 2001; Petersen 2002), while a related strand has looked more at the structure of institutions or relations in society that might serve to ameliorate these types of socially embedded tensions (Fearon and Laitin 1996; Kopstein and Wittenberg 2011). For example, Varshney's (2003; see also Jha 2013) study of anti-Muslim riots in India shows that cross-ethnic associational ties, often based around business organizations, tend to mitigate violence. 
If these studies emphasize the importance of economic institutions for reducing tensions, other scholars have pointed to the centrality of economic competition between ethnic groups to violence (Olzak 1992; Sniderman et al 2000; Esteban and Ray 2001; Urdal 2008; Dancygier 2010).

A third major cluster of explanations proposes that ethnic violence occurs with a political calculus. Violence may be an effective means by which to demobilize opponents, rally supporters, and elevate the salience of ethnic differences ahead of an election or another important political event (Wilkinson 2004; Dhattiwala and Biggs 2012; Toha 2017). It may also occur when ethnic groups begin to develop autonomous political power through superior organizational or mobilizational skills (Dancygier 2010). Often these explanations focus on the mobilizational role of political entrepreneurs who use ethnically-charged speech to heighten animosities between groups, provide explicit or tacit encouragement to assailants, or even directly organize followers to participate in collective attacks (Hardin 1997; Karapin 2002; Wilkinson 2004).

A final set of explanations that are less often evaluated relate to the drivers of terrorist violence. Though terrorism has often been analyzed separately from ethnic violence, in fact terrorists do often target ethnic minorities, and in some cases terrorist violence may have connections to longer term patterns of inter-ethnic hostilities (Sidel 2006). In particular, recent contributions to studies of Islamist terrorism point to the importance of the Islamic calendar in patterning violence (Hassner 2011; Toft and Zhukov 2015; Reese et al 2017). While some scholarship identifies Muslim holidays as "days of restraint" (Reese et al 2017), when Islamist militants reduce their activities, in contexts where terrorist groups target religious out-groups, we might expect the congregation of those groups on religious holidays to heighten the likelihood of their being targeted. It also follows that Islamist terrorist attacks targeting religious minorities will be more likely in areas proximate to ongoing insurgencies.

Of course, it is not surprising that studies of ethnic violence have detected no single set of drivers; like all complex political processes that produce collective action, it may occur for different reasons in different times and places. Still, the range and diversity 
of arguments in the literature are striking. Some of these explanations generate predictions that are directly contradictory (e.g., strong ethnic leaders may discourage violence to preserve intercommunal societal harmony or they may encourage violence to achieve political gain). And though scholars do analyze a range of cases, some of these rival explanations emerge from studies of the same case — and occasionally even from analysis of the very same dataset. The most famous example is the disagreement between Wilkinson (2006) and Varshney (2003), who collaborated to collect data on ethnic riots in India from 1950 to 1995, but came to different conclusions regarding the drivers of this violence: the former privileging political and state-centric factors, the latter preferring a societal explanation.

We believe that such diverse and contradictory accounts may be indicative of a more general problem in the ethnic conflict literature. Following Sartori (1970), who cautioned against conceptual lumping and stretching, we propose that scholars may be studying the phenomenon at too high a level of aggregation, grouping together different types of violence that in fact have distinct drivers and logics even if the targets of that violence share a common ethnic hue. A brief survey of the different forms of action that scholars have considered under the common heading of "ethnic violence" confirms the intuition. Many studies use the "ethnic riot" as the unit of analysis, typically defined as an attack by one ethnic group against another (Horowitz 2001; Varshney 2003; Wilkinson 2006; Toha 2017). Others consider the more specific phenomenon of pogroms (Kopstein and Wittenberg 2011; Dhatiwalla and Biggs 2012), presumably more deliberate campaigns to inflict mass casualties on a minority group, including efforts organized by the state (though the distinction between pogroms and riots is not entirely clear). Other scholars consider more large-scale forms of violence, for example, why ethnic groups might choose to rebel against the state (Toft 2003; Cederman et al 2010; Tezcür 2016) or engage in ethnic insurgencies (Reese et al 2017). Still others conduct cross-national research that looks at the macro level emergence of ethnic civil wars (Lieberman and Singh 2012; Sambanis 2001; Buhaug et al 2008; Borman et al 2017). Some scholars lump together diverse forms of violence in the same study. For example, Olzak studies "ethnic collective 
action," which she defines as "a public action of two or more persons that articulates a distinctly ethnic (or racial) claim, expresses a grievance, or attacks members of another ethic group (or property)" (Olzak 1992: 6). Here, then, we have action that is nonviolent (e.g., a protest) and violent (e.g., a riot), targeted against both individuals and properties, all bundled together. Following Olzak, Varshney (2003) and Wilkinson (2006) define an ethnic riot as an event involving violence in which two or more communally identified groups confront each other - a definition that encompasses large- and small-scale attacks against both individuals and properties from the opposing group, using various levels of arms (see Wilkson 2006: 255-6). Dancygier's (2010) work on immigration-related violence similarly groups together various forms of immigrant-related violence, including relatively isolated racist attacks by small groups or individuals and large-scale riots aimed at physical property destruction.

Occasionally scholars have been more attentive to the potentially diverse manifestations that ethnic violence can take. For example, Karapin's (2002) study of antiminority violence in Germany distinguishes between "small-scale violence" and larger "antiminority riots," interrogating why the former sometimes telescope into the latter. Paul Brass (1997) asks a similar question in India: why do small, parochial incidents (like "the theft of an idol") sometimes escalate into large-scale riots or pogroms. Another example is Sidel's (2006) account of religious violence in Indonesia, which places the rise of Islamist violence in the country within a much longer historical arc of religious violence (including both anti-minority riots and pogroms). Sidel's work is also notable for being one of the few that integrates the study of terrorism into a broader ethnic violence framework.

Building on these examples we propose that by disaggregating ethnic violence into its different forms, scholars can better analyze its diverse logics and drivers and reconcile some of the competing findings in the literature. This call for disaggregation has already been aired by prominent voices in the field, even if it has not found its way into empirical work. For example, Snyder (1978: 524) argued that, unless we properly specify what is included in our definition of collective violence, any inferences derived from statistical analyses will be "vitiated by improper measures of the dependent variable." Brubaker and 


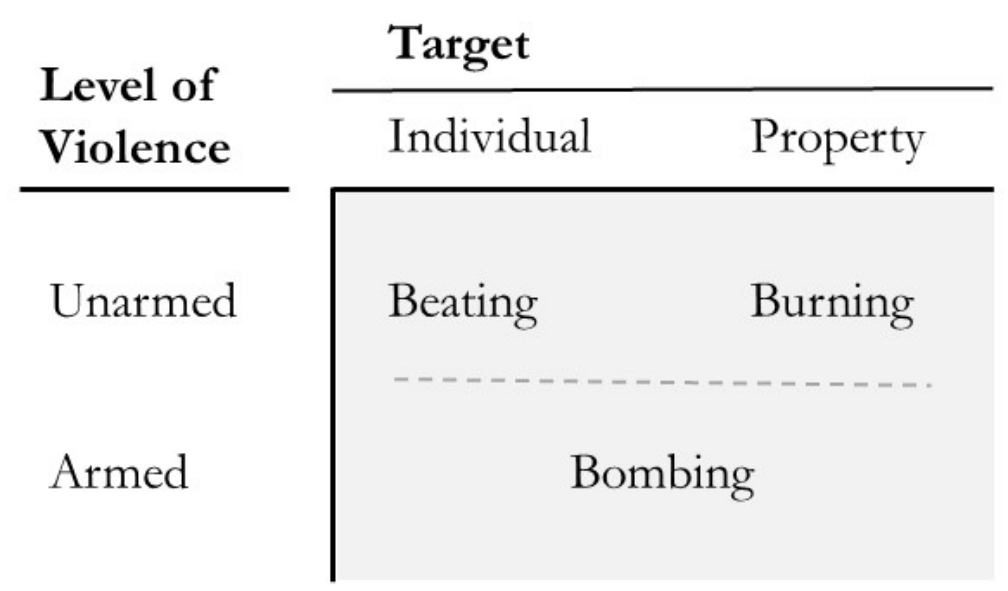

Figure 1: A typology of ethnic violence

Laitin have cautioned against defining a "research program around an aggregated notion of ethnic violence" (Brubaker and Laitin 1998: 446). In their "plea for disaggregation" they argue that ethnic violence is "composite and causally heterogeneous" and "involve[s] sharply opposed mechanisms and dynamics" (Ibid). Horowitz has made a similar point; while noting that "riots almost surely share some causal elements with other forms of ethnic violence," he argues that it will "not be possible to know which conditions are common and which are distinctive if we begin with a dependent variable based on merged phenomena" (Horowitz 2001: 27-28). We now turn to an elaboration of one approach that scholars might use to disaggregate ethnic violence into its various "merged phenomena."

\section{Disaggregating ethnic violence}

Ethnic violence is often defined as any violence in which animosities based on differences in ethnic identity are a primary motivation for action (e.g., Brubaker and Laitin 1998: 428). According to this and similar definitions it is the character of the conflict that sets it apart as a common type. Our proposal is that ethnic violence be further disaggregated according to two criteria: the target of the violence and the level of arms used (see Figure 1). We select these criteria for two reasons: 1) they are substantively meaningful, i.e., they capture important differences in the forms and functions of violence, including the aims of that violence and its level of organization; and 2) they are tractable, i.e., they are easy to apply based on even cursory or limited information about an event. 
We begin by differentiating between attacks against individuals from another ethnic group (like assaults or kidnappings) and attacks against properties owned by members of another ethnic community (like arson or looting). We term the first type of attacks "beatings" and the second type "burnings." The logic behind this distinction is that the target of an attack says something important about the motivations of the attackers. An attack against a specific individual or group of individuals likely has a retributive rationale; the violence is intended to punish that individual or group for some perceived affront. In other words, the targeting of individual members of an ethnic community entails that ethnic hostilities are narrow and focused, and that the intention of the violence is to punish a specific individual or group of individuals for a specific supposed wrongdoing. ${ }^{2}$ In contrast, an attack against a physical property associated with an ethnic community is much more likely to be motivated by a desire to punish an entire community or population, rather than some specific individuals. Such physical properties typically have symbolic importance, particularly if they are cultural sites or places of worship, and their desecration or destruction is often undertaken with the aim of collective punishment. In this sense, by distinguishing between the target of ethnic attacks we capture meaningful differences in the ends to which that violence is undertaken. ${ }^{3}$

The second axis of disaggregation is the level of violence used. Drawing on Tilly's (2003) work on collective violence, we distinguish between armed ethnic violence, which inflicts damage on an ethnic group or its members using firearms or explosives, and unarmed violence, which inflicts harm using improvised weapons (e.g., clubs, knives, or fists). We refer to armed attacks as "bombings," which captures both attacks using bombs and those using guns, like shootings or assassinations. We believe this distinction is impor-

\footnotetext{
${ }^{2}$ One could imagine further disaggregating this category of violence into attacks against an individual (i.e., one person) versus attacks against groups (i.e., more than one person). It could be argued that the latter has important similarities to what we call burnings (attacks against properties), in that an attack against a group is an effort in collective punishment. However, we found that attacks against groups more often followed the retributive logic of individual attacks, and that furthermore it was difficult in practice to determine the number of individuals targeted in an attack.

${ }^{3}$ Of course, there are instances in which individuals are harmed with an eye toward collective punishment (e.g., lynchings in the American South). And desecration of property can be undertaken with an eye toward punishing the specific property-owner (e.g., burning down an offending individual's house). Still, on average, the targeting of individuals tends to have retributive aims whereas the targeting of properties aims at collective punishment.
} 
tant because it captures important differences in the perpetrator's level of organization. Indeed, Kadivar and Ketchley (2018) have pointed out that armed and unarmed violence is generally undertaken by markedly different types of actors. In the context of ethnic violence, we expect that armed violence requires some sponsoring organization, like a vigilante group, a terrorist organization, or a branch of the state's coercive apparatus, to furnish the weapons. These weapons are not readily available to most citizens, requiring a group with some level of organization and funding to acquire and distribute them. In contrast, unarmed attacks will, by and large, be perpetrated by normal citizens, who lack access to advanced weapons and firearms, and instead draw on improvised weapons that are at their immediate disposal (like sticks, clubs, stones, knives, and fists). Further, in contrast to armed violence, which requires some of level prior planning to procure and distribute the weapons to the relevant actors, unarmed violence can emerge rapidly and spontaneously, since assailants rely on whatever improvised weapons readily at hand.

Importantly, we choose not to subdivide armed violence according to the target of the attack (as we do with unarmed violence). The reason is that we believe that once advanced weapons are involved the distinction between attacking individuals and properties is no longer meaningful. Attacks involving such weapons are almost always aimed at inflicting maximum civilian casualties and terrorizing an entire community. It is rare to involve advanced weapons in attacks aimed at individual punishment for a specific act. ${ }^{4}$ For this reason, we keep this category merged, and define it solely according to the types of weapons involved, which suggest a particular level and type of organization.

There are, of course, other ways that one might envision disaggregating ethnic violence. For example, some scholars have proposed breaking down "ethnicity" into its different potential sub-forms — e.g., race, religion, or language (Bormann et al 2017; Vogt 2018). Another possibility would be to differentiate according to the size of the ethnic groups involved (e.g., anti-minority violence, anti-majority violence, violence between equally sized groups). However, these distinctions may make more sense for comparative work across cases, rather than analysis within a single case (like Egypt) where there is

\footnotetext{
${ }^{4}$ The exception to this would be targeted assassinations against individuals who have committed some specific offense - but we do not believe that such incidents are common.
} 
one primary ethnic cleavage (religious) and one primary type of violence (anti-minority).

Two other obvious candidates for disaggregation criteria would be the perpetrator of the violence and the scale of the violence. For example, one could envision differentiating between different types of social or political groups behind an act of violence (e.g., the state, a political party, a vigilante group, a neighborhood group, etc.). And one could imagine operationalizing the scale of violence with a measure of the number of participants involved. The problem with both of these measures is that they can be difficult to implement in the actual coding of cases. It is often unclear whether a particular group or sponsor is behind an attack, as they may want to keep this information hidden. And we found in our data that the number of participants in an attack is often omitted or unreliable in the underlying reporting of the incident. Furthermore, we believe that the categorization scheme we have laid out above does a good job of capturing the most important differences in perpetrator and scale. We have already discussed how level of violence (armed versus unarmed) is a meaningful proxy for the perpetrator's level of organization and resources. And, for scale, it is fair to assume that attacks against a single person or a small number of individuals will involve fewer assailants, whereas attacks against properties require the mobilization of large mobs or crowds, who can surround a building and overwhelm security forces.

In sum, our three-part categorization of ethnic violence - beatings, burning, and bombings - is based on distinguishing between the target of the violence and the level of arms used, and in doing so captures important differences in why the violence is undertaken and by whom. Because of these substantive differences, we expect the drivers of these different forms of violence to be somewhat distinct; in other words, we expect them to occur in different times and places. Indeed, as we suggested above, one of the reasons the ethnic conflict literature may have forwarded so many competing findings is that the different theories may be better suited to explaining some of these forms than others. 


\section{Ethnic violence in Egypt, 2013-2018}

In a first attempt to show the value of disaggregation, we describe trends in anti-Christian violence in Egypt from 2013 to 2018. Here, we make sense of these events through an examination of human rights reporting and the qualitative descriptions of anti-Christian violence contained in local media reporting, as well as the broader case literature on the 25th January Revolution in 2011 and its aftermath. We illustrate these trends using our catalog of anti-Christian events, which we introduce more fully in Section 5 .

\subsection{Christians and the 25th January Revolution}

Many Coptic youth and prominent Coptic figures participated in movements against the regime of Hosni Mubarak during the mid-2000s (Clarke 2011; Rowe 2013; Fahmi 2014), and they joined in the early protests of the 2011 revolution, despite the Church's lack of support for the uprising (el-Ghobashy 2011; Clarke 2014). Indeed, Tahrir Square was heralded during the revolution as a space of striking cross-confessional solidarity, with Muslims and Christians protecting each other from attacks during their respective days of worship.

But the strong sense of national unity that had subsumed sectarian divisions during the revolution quickly faded away as Egyptians set about the messy business of constructing a new political regime. In the months following Mubarak's resignation anti-Christian attacks occurred in Helwan, Qena, and Imbaba (Tadros 2013; Brownlee 2013). And Egypt's Coptic community became increasingly concerned by the growing power of domestic Islamist forces, especially the Muslim Brotherhood. The Brotherhood and its more radical allies in the Salafi movement swept parliamentary elections in late 2011, before the Brotherhood candidate, Mohamed Morsi, won the presidency in mid-2012. As the group set about the drafting of a new constitution, Christians came to fear that they were witnessing the emergence of a permanent Islamist hegemony in Egypt. Coptic elites were therefore some of the most active participants in the counterrevolutionary movement that paved the way for Abdel Fattah al-Sisi's July 2013 coup, which ousted Morsi and 


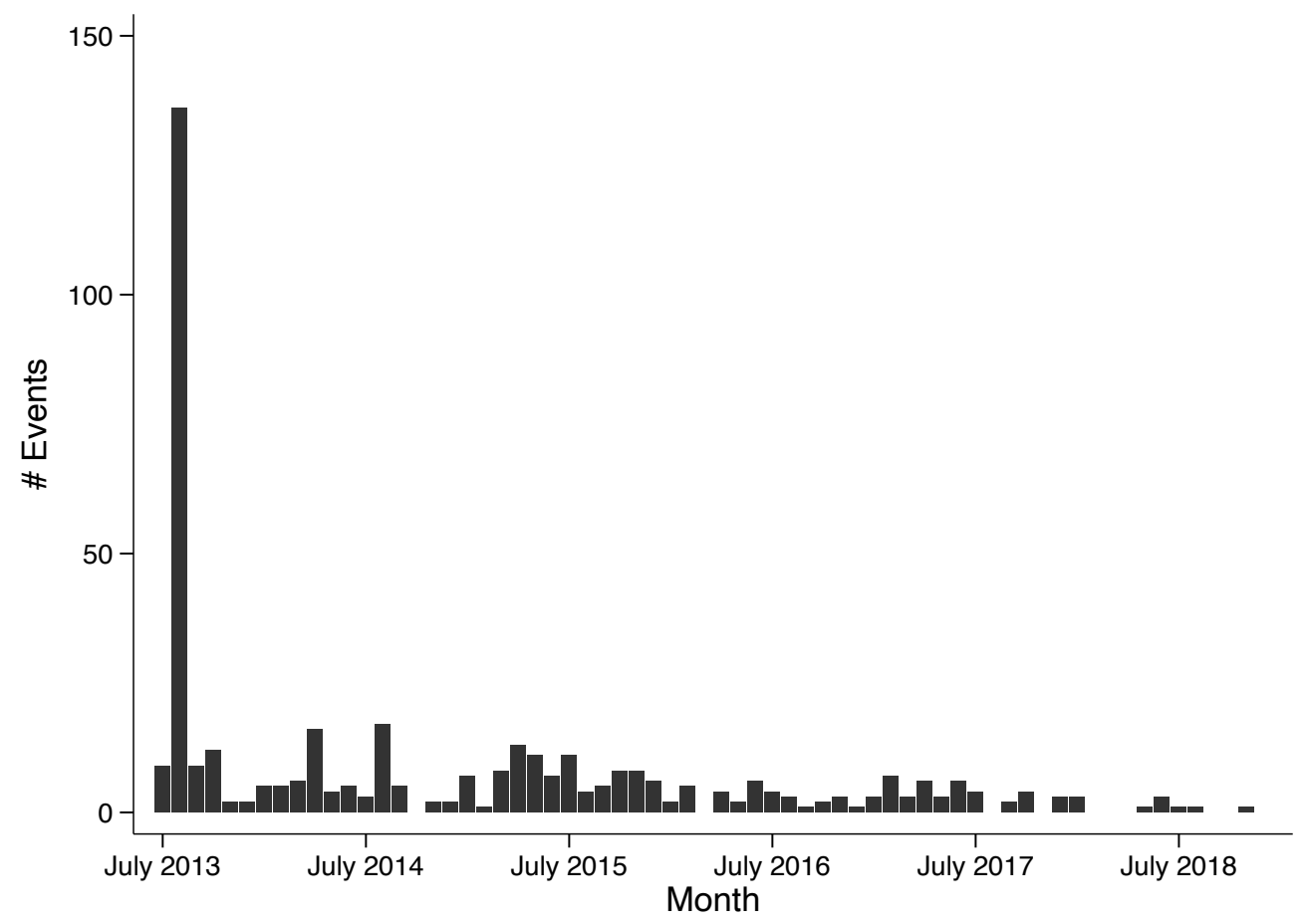

Figure 2: Anti-Christian attacks, July 2013-December 2018.

restored military rule.

\subsection{The Rabaa massacre}

Against this backdrop, we can now turn to an analysis of the patterns of ethnic violence that marked the months and years following the July 2013 coup. Figure 2 plots the number of ethnic attacks per month from July 2013 to December 2018.

The figure depicts a striking spike in attacks in August 2013, followed by lower levels of violence over the subsequent five years. This sudden explosion of violence was triggered by a series of political events in Cairo that followed the coup. When Morsi was ousted by the military the Muslim Brotherhood responded with massive street mobilization; hundreds of thousands of their followers converged on a square in front of Rabaa al-Adwiyya mosque in Cairo and swore not to leave until Morsi had been restored in office (Ketchley 2017). On August 14 the military-led government reacted with a brutal and bloody crackdown, killing approximately 1,150 people in one of the most vicious acts of state repression witnessed anywhere since the end of the Cold War (Human Rights Watch 2014). In response, local Muslim Brotherhood branches and allied Islamist groups went on the 
attack. One of their primary targets were Christian communities, whose members they blamed for backing the coup and thus enabling the massacre of their supporters. Event data indicates that members of these groups were implicated in 129 attacks following the Rabaa Massacre, many of which targeted Christian churches and other institutions used by the Christian community. Moreover, though the trigger for these attacks were political events in the capital, the violence was national in scale, occurring in 16 of Egypt's 27 governorates, with a particular concentration in the more heavily Christian governorates of Upper Egypt (e.g., Minya, Asyut, and Beni Souef).

A report published in the aftermath of these attacks by the Egyptian Initiative for Personal Rights (EIPR) provides rich qualitative insight into the central role of political entrepreneurs from the Muslim Brotherhood and other Islamist groups in orchestrating this violence. The report summarized the events as follows:

Most of the churches were set on fire by marchers supporting the deposed president, and some of the marches set out from sit-ins, as in cities in Minya, Assyout, and Sohag. In other cases, such as in cities and districts in Fayyoum, Minya, and Giza, appeals went out to attack churches from mosques known to be dominated by Islamist currents (Egyptian Initiative for Personal Rights 2014: 95)

The EIPR report also includes first-hand accounts from individuals who witnessed the attacks. For example, the priest of the Mar Girgis Church in Minya described an assault on a Christian orphanage:

What happened is that on Wednesday, 12 August, the day they cleared the Nahda and Rabaa sit-ins, a huge group of terrorists ${ }^{5}$ came and attacked the place here. As you can see, the building here was burned to the ground with everything inside it, after they took whatever they could carry. It was an organized operation, first looting and theft then burn it down (Ibid: 97)

\footnotetext{
${ }^{5}$ It is common in Egypt for those who oppose Islamist political ideologies to refer to members of Islamist parties and movements as "terrorists."
} 
In addition to churches and other communal sites, the report also discusses the deliberate targeting of Coptic-owned homes and businesses by similar crowds of Morsi supporters.

A second important source of insight on the attacks comes from an unpublished report authored by the Egypt-based researcher Steve Negus, based on field reporting nine months after the episode (Negus n.d.). The report focuses on the Upper Egyptian governorate of Minya, where the three episodes discussed in the introduction of this paper took place. Minya has long been an epicenter of anti-Christian violence in Egypt, due to an explosive mix of demographic conditions: it is both an Islamist stronghold and also hosts the largest proportion of Christians of any governorate in Egypt (one-third of the population) (Ibid: 3-5). In our dataset it is the governorate with the greatest number of violent events, both during the Rabaa week and otherwise. Negus's reporting confirms that the anti-Christian attacks in the governorate following Rabaa were instigated by supporters of Mohamed Morsi and mosque preachers aligned with the Brotherhood. ${ }^{6}$ Moreover, witnesses he interviewed confirmed that "the attackers were more interested in burning and in looting computers, wiring, and other valuables from the churches than in attacking people" (Ibid: 19). He also found that, by and large, these attacks did not involve weapons: "while some people might have brought arms to the attacks, these were crowd assaults not armed assaults" (Ibid: 20). Finally, Negus found considerable evidence that police inaction in the governorate allowed the violence to spiral out of control. Local police forces in the south had been cowed by the experience of the 2011 revolution, and they had withdrawn from the streets in many places, refusing to man checkpoints, respond to crime reports, or go out on patrol. Their disillusionment only increased when Morsi was elected president, as many police officers have long-standing animosities towards the Brotherhood. During the Rabaa violence, Negus reported that many police forces lacked the confidence and resolve to confront the Islamist mobs, and simply holed up in their stations or abandoned them entirely (Ibid: 19).

\footnotetext{
${ }^{6}$ Negus also notes that "Brotherhood mouthpieces produced a flood of statements blaming the Church, and sometimes Christians in general, for backing the overthrow of Morsi" and that this discourse may have helped to create the conditions for post-Rabaa violence (Negus n.d.: $18)$.
} 


\subsection{Low-scale attacks and harassment}

In the months after the Rabaa attacks sectarian violence in Egypt receded, as can be seen in Figure 2. September, 2013 saw only 9 attacks, October saw 12, and November and December saw 2 each. The average rate of monthly attacks over the four years following Rabaa was 6, and no month contained more than 20 attacks. There is also a meaningful qualitative shift in the types of violence that mark this period. In general, the violence is far more localized and lower-scale, with issues like church construction, intermarriage, and religious conversion catalyzing attacks that rarely result in serious injuries or deaths. For example, in January 2014 a Christian man's home was burned in Qena when a rumor began circulating that he was having an affair with a Muslim girl. The same month, in Asyut, a brawl ensued when several Muslim boys were called out for harassing a Christian girl. In the spring of the following year the village of al-Galaa in Samalut, Minya saw a series of clashes and attacks against Coptic individuals in response to plans to build a new church. Another common form of attack was the abduction of Christians for ransom. For example, in September and October 2013 a number of Christian doctors and medical professionals were kidnapped and held for ransom in Minya province.

\subsection{Anti-Christian terrorism}

In addition to politically-motivated riots and small-scale parochial attacks, the trends in our data point to a third wave of ethnic violence that was operative in Egypt during this period. Figure 3 below plots the number of monthly deaths from sectarian violence from July 2013 to December 2018. In contrast to Figure 2, which showed a relatively steady rate of incidents from 2014 to 2018, the figure shows a striking increase in the intensity of violence beginning in late 2016, with spikes in deaths occurring in December 2016, April 2017, and May 2017.

The trend can be attributed to a wave of terrorist violence staged by the Islamist militant group Ansar Beit al-Maqdis (ABM), which was formed in the Sinai Peninsula immediately after the 2011 revolution. Militants took advantage of the collapse of the security state to essentially take control of large parts of the Sinai, and they soon be- 


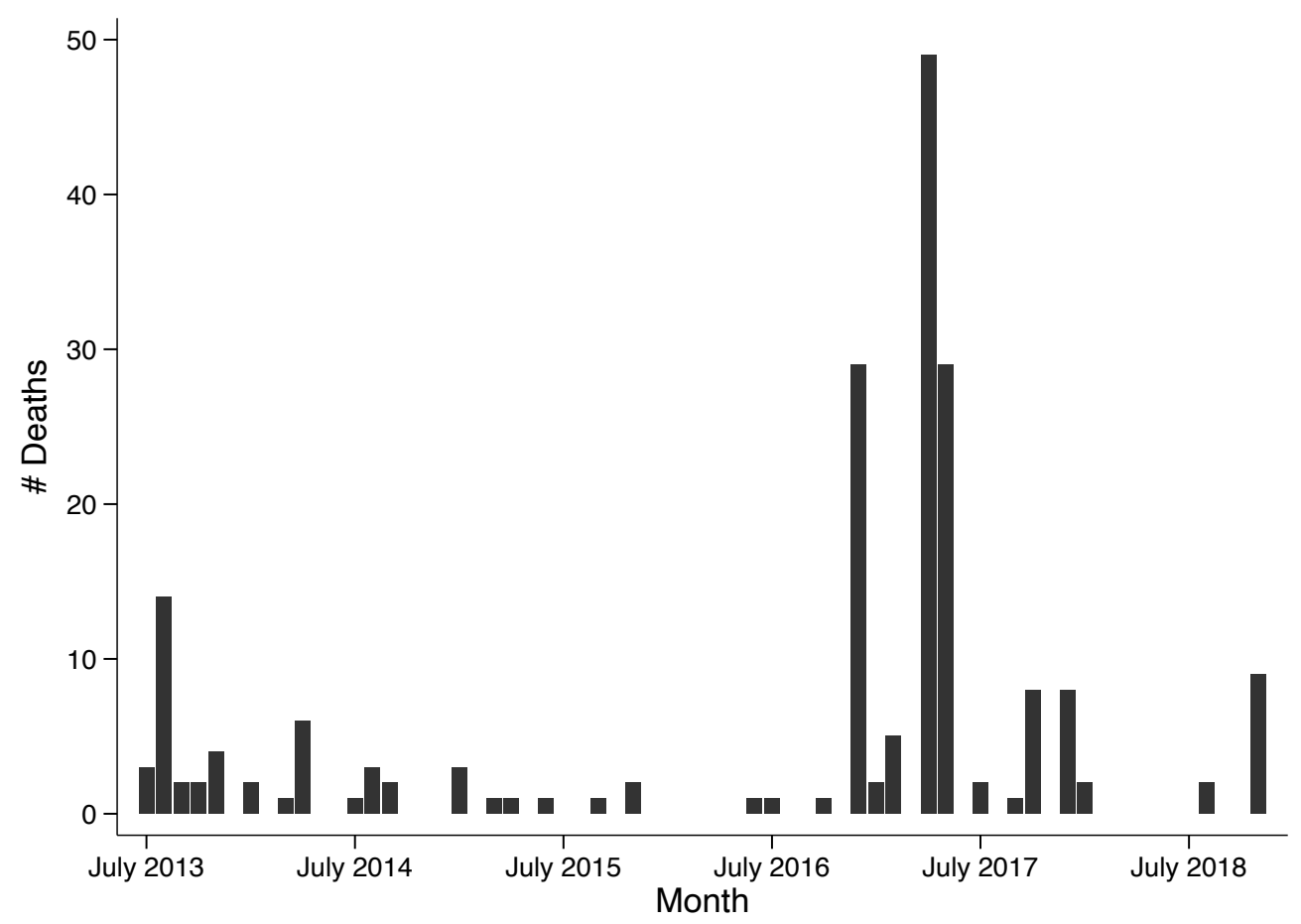

Figure 3: Christian deaths from ethnic violence, July 2013-December 2018.

gan staging attacks against security forces, infrastructure, and civilians. These attacks increased in the aftermath of the 2013 coup, as the organization began to recruit more followers from among the disillusioned supporters of the Morsi government (Awad and Hashem 2015). Then in November 2014 ABM publicly declared allegiance to the Islamic State, claiming it was the Egypt affiliate of the transnational terror organization. The group then staged a number of increasingly audacious attacks, many of which targeted Egypt's security forces, which the group considers its primary enemy (al-Anani 2014; Awad and Hashem 2015; Burt 2017). However, the organization has also attacked Coptic communities, including by bombing Coptic churches and staging armed assaults on groups of Copts. In line with the logic of terrorist violence elsewhere (Crenshaw 1981; Byman 1998; McCormick 2003), these attacks target symbolically important sites with spectacular acts of violence intended to maximize the number of civilian casualties, which serves simultaneously to incite fear in minority communities, to increase the exposure of the terrorist group, and to radicalize and mobilize potential supporters.

Overall, then, the analysis above suggests that from 2013 to 2018, Egypt was racked by three distinct types of ethnic violence. First, following the massacre of Islamists in Rabaa 
Square on August 14, 2013, was an outburst of politically motivated rioting involving Morsi supporters targeting sites of communal importance to Christians. Second was the persistent targeting of Christians in low-scale attacks and kidnappings prompted often by parochial issues related to church construction, intermarriage, conversion, and other perceived affronts to communal and religious identity. Third, was a surge of Jihadi-inspired and militant-sponsored attacks of Christian religious sites and communities intended to maximize casualties and incite a sectarian war.

\section{Data and method}

Our principal data source to examine this violence is the Esshad catalog of anti-Christian events in Egypt over the period 2013-2018. The catalog draws on more than fifty Arabicand English-language news sources. ${ }^{7}$ We cleaned these data, and assigned each event to its census district. Given the potential for "news holes" (Oliver and Maney 2000) during periods of particular violent upheaval, we expanded the dataset for the intense period of violence following the 2013 Rabaa massacre using human rights reports compiled by the Egyptian Initiative for Personal Rights and Human Rights Watch. These sources yielded 54 additional events. We also removed some events from the dataset, either because the details of their occurrence were difficult to verify (e.g., accounts of events shared on Facebook) or because they did not meet the criteria for a sectarian attack (e.g., it was not clear that violence actually occurred, or that the motivation for the attack was sectarian in nature). Ultimately, we ended up with a dataset of 413 anti-Christian attacks.

For each event, the dataset recorded the date of its occurrence, the location (governorate and district), the number killed and injured, and the main narrative details. We used these narrative details as well as, in some cases, the underlying source text to code each event into our ethnic violence categories. The following definitions guided our codings: beatings were defined as events in which improvised weapons were used to inflict harm on individuals; burnings as events in which improvised weapons were used to inflict damage on physical property; and bombings as events in which firearms or ex-

\footnotetext{
${ }^{7}$ For more information on Eshhad, see https://eshhad.org/about-us.
} 
plosives were used to inflict harm on individuals or physical property. Typically, events could easily be assigned to one of these three categories. For example, the type of target that had been attacked was relatively straightforward to determine; usually a narrative would explicitly mention that a building had been mobbed, burned, or looted, or that an individual person had been, for example, abducted or beaten. For those events where individuals were injured during an attack on a building, the event was still coded as a "burning" because the main target of the attack was a property. The only borderline cases (which were rare) occurred when an individual was hurt in front of or in the vicinity of a building, and it was unclear whether the building or the person was the main target of the attack. Determining whether weapons were used was even more straightforward; whenever a narrative mentioned that a firearm or bomb was used in an attack, the event was coded as a "bombing." The only borderline cases (which, again, were rare) were those in which assailants carried weapons but did not use them, or fired their weapons into the air. As an indication of the ease with which our typology can be applied, three coders independently reached consensus on the coding of 94 percent of the events in the dataset. For the 29 events where coders were in disagreement, mostly due to ambiguities like those noted above, we used the categorization agreed on by two of the three coders.

To explain the different conditions and temporal dynamics that produced this violence, we make use of a range of additional source material. To capture the social contexts of anti-Christian violence, including the distribution of Christians, we use the 2006 Egyptian census. Our theoretical intervention stresses the importance of symbolic institutions as distinct targets for ethnic violence. To account for this, we created a district-level dataset of Coptic churches taken from online lists compiled and distributed by Egypt's Coptic community. ${ }^{8}$ We use data compiled by Ketchley and Biggs (2015) on the home districts of those killed at Rabaa to measure local backlash. Data from the Egyptian Central Bank allows us to account for economic trends. To measure local instances of co-ethnic mobilization, we draw on district-level event data compiled by Ketchley (2017) recording instances of Muslims and Christians staging joint protests in the post-Mubarak ${ }^{8}$ See https://st-takla.org/Coptic-History/places/africa/egypt/cairo/index.html. 
democratic transition. Political competition is captured using disaggregated electoral data from the 2012 Egyptian presidential elections. We also make use of event data from Islamist publications recording the locations of anti-coup protest occupations (Ibid.). To gauge local-level state coercive capacity, we draw on a dataset of 143 police strikes from the pre-coup period reported in the Egyptian Arabic-language daily newspaper al-Masry al-Youm (Clarke 2020). Finally, to measure proximate terrorist activities, we use the Global Terrorism Database (GTD), which contains records for 1,797 terrorist events in Egypt during our analysis period.

\subsection{Dependent variable}

To assess how different geographic and temporal predictors explain the three categories of ethnic violence that we have laid out, let $y$ be the dependent variable with $J$ nominal categories coded as "2" for a district-day that witnessed a beating, "3" a district-day that

witnessed a burning, and "4" for one that witnessed a bombing. The base category (set as "1") records district-days on which no event took place. This is naturally analyzed using multinomial logistic regression, where the occurrence of sectarian violence in district $(i)$ located in a governorate $(g)$ on a given day $(t)$ is predicted as:

$$
\operatorname{Pr}\left(y_{i g t}=m \mid x_{i g t}\right)=\frac{\exp \left(x_{k i g t} \beta_{m}\right)}{1+\sum_{j=2}^{J} \exp \left(x_{k i g t} \beta_{m}\right)} \text { for } m>1
$$

where $m$ is the specific event type to be predicted, and $x_{k}$ is a vector of time-varying and time invariant independent variables measured at the district and governorate levels. Our data structure is thus a hierarchical panel, and so twoway standard errors are clustered on the governorate and district. A Wald test confirms that our outcome categories are statistically distinct from one another $(\mathrm{p}<.001)$ as a function of our independent variables. 


\section{$5.2 \quad$ Independent variables}

The literature on ethnic violence highlights the importance of a state's coercive capacity. In early 2013, local police forces in Egypt launched a national wave of strikes, demanding higher wages, better equipment, and more institutional support. In some instances, these strikes were staged in a deliberate effort to destabilize the Morsi administration. Thus, we enter a variable measuring the number of police strikes in a district transformed to its square root. If police officers in districts that saw strike action lacked the resources and resolve to curtail different forms of ethnic violence, or deliberately facilitated this violence in an effort to further tarnish the reputation of the Muslim Brotherhood, this variable should be positive. To capture the effects of state repression and ethnic backlash, we include a dummy variable for the seven days following the Rabaa massacre. If the mass killing of Morsi supporters at Rabaa increased the likelihood of different types of ethnic violence being committed, this variable should also be positive. We might also expect that areas where the relatives of those who died at Rabaa lived would be more likely to lash out at proximate Christians. To account for this, we include the square rooted count of individuals of those killed at Rabaa by their home district. Again, we expect this variable to be positive.

We test the importance of economic competition with a measure of monthly percentage Consumer Price Index (CPI) change. This captures increases in the cost of living. If members of different ethnic groups turn to one of our three categories of violence as a consequence of economic strain, this variable should be positive. Following the literature on coethnic cooperation, we enter a count of coethnic protest events in a district in the pre-coup period, transformed by taking its square root.

We use two measures to account for the potential role of political organization and competition in producing either beatings, burnings, or bombings. To account for popular support for the Muslim Brotherhood, we enter the percentage of the vote won by the Muslim Brotherhood's Mohamed Morsi in the first round of the 2012 presidential election. After the July 2013 coup, the Muslim Brotherhood mobilized its members and supporters to occupy a number of squares and major thoroughfares around the country, 
where they remained until the Rabaa massacre in mid-August 2013. As a measure of local organizational capacity, we use a binary variable for whether an occupation was currently taking place in a district. An alternative version of the political competition hypothesis sees ethnic violence as a tool used by institutional actors to consolidate ethnic cleavages for political gain. Thus, we also enter a variable measuring the percentage of the vote won by Ahmed Shafik, the candidate favored by the majority of Egypt's Coptic community. As per Dhattiwala and Biggs (2012), we would expect any effect here to be non-monotonic, i.e., that violence will be higher at intermediate levels of vote support for Shafiq, and so include a quadratic term.

Following the literature on Islamist terrorism and violence, we include measures for both Muslim and Christian holidays to assess how the religious calendar might pattern ethnic violence. We also include a dummy variable for whether the day in question is a Friday: following the repertoire of the 25th January Revolution, ritual confluence at places of worship were used as focal starting points for anti-coup protests, and so may also have provided a launching point for anti-Christian attacks. In the qualitative analysis above, we found that some of the patterns in ethnic violence could be explained by the rise of an Islamist terrorist organization. To further probe the relationship between terrorist organization and attacks against Christians in Egypt, we use three variables that measure the presence of terrorist activities. First, we include a one-week lagged square root sum of terrorism events in a particular governorate. Second, we use a (square root) measure of the distance between a given district and the governorate of North Sinai, where ABM were especially active. We also suspect that ethnic violence sponsored by terrorist groups may occur in major urban centres where it will garner maximum attention from local and international audiences. We therefore take the district where each governorate's administrative headquarters (Diwan) are located, and construct a distance measure (square rooted) for each district from its centroid to the centroid of the district where the governorate headquarters is located.

We also include a number of contextual variables to account for plausible confounding. To account for the underlying population of Christians and Christian religious infrastruc- 
ture in a district that was at risk of being targeted we include two measures: the logged number of Christians in a district and the number of Coptic churches (square rooted). We also include various measures of the demographic characteristics of a district (the percentage of population employed in agriculture, percentage with a university degree, and population density) in case more rural, urban, or educated districts have a higher or lower tendency toward ethnic violence. To measure any inertial effects of violence, we include a one-day-lagged binary indicator of any type of ethnic violence in a district.

\section{Results}

Our results are reported in Table 1. Model 1 begins with our contextual variables and those measures capturing state capacity and the effects of state repression. Model 2 introduces measures for economic competition and coethnic mobilization. Model 3 adds our political competition variables. Model 4 adds measures for holiday periods and terrorism. Moving from Model 1 to Model 4, there is a substantial reduction in Akaike information criterion. Coefficients are expressed as relative risk ratios (the exponent of $\beta$ ) and thus represent the risk of an event type occurring relative to the base category of no event.

The large number of coefficients and test statistics complicates reporting the results from multinomial models. For the sake of simplicity, we concentrate on the findings from Model 4, which is akin to the full model, where all theoretically relevant covariates and contextual variables are observed. Marginal effects for statistically significant continuous variables are reported in Figure 4. A strength of a multinomial modelling approach is that we can also test whether one event type is more likely to occur relative to another. We visualize between-outcome differences as a link plot in Figure 5. The panels in Figure 5 report all variables from Model 4. The position of each outcome (No-no event; Bebeating; $\mathrm{Bu}$-burning; $\mathrm{Bo}$-bombing) relative to the two horizontal axes indicates the size of the coefficient for each variable listed on the left hand side. ${ }^{9}$ For factor variables, the odds ratios (logit coefficients) refer to the effect size of a 0-1 change in the variable;

${ }^{9}$ The vertical position has no interpretation - positions are chosen for ease of visualization only. 
for continuous variables the odds ratios (logit coefficients) represent the expected effect of a one standard deviation increase. Since tests of between-outcome significance involve multiple comparisons, we confine attention to between differences that are statistically significant at $\mathrm{p}<.01$. Outcomes are linked by a dotted line when the between-outcome significance is not statistically significant at $\mathrm{p}<.01$. In other words, when there is no line between one outcome and another, the coefficients on these outcomes are significantly different from each other with respect to the variable of interest.

Beginning with our contextual variables, the number of Christians in a district is a substantive and significant predictor of beatings and burnings. A one standard deviation increase in the Christian population multiplies the relative risk of beatings by 4.44 times and burnings by 1.99 times (Figure 4a). Comparing across event types, beatings were much more likely in districts with more Christians than either burnings or bombings, and this difference is itself statistically significant at $\mathrm{p}<.01$. The availability of more Christian religious infrastructure in a district is also a positive and significant predictor of beatings, burnings, and bombings (Figure 4b). The coefficient for employment in agriculture in a district is positive for beatings and negative for burnings and bombings; however, we cannot reject the null hypothesis of no association at $\mathrm{p}<.05$. Likewise, the coefficient for university education is positively associated with beatings and burnings and negative for bombings - but again, these do not approach statistical significance at conventional levels. Compared to the base category of no attack, beating events were 1.83 times more likely following a violent sectarian event the previous day, while the risk of a bombing attack increased by 27.9 times, and the difference in the size of these association is itself statistically significant. Population density is negatively associated with all three event types, but this fails to attain significance.

Turning to state-centered explanations: both beatings and burnings were significantly more likely in districts that had recently witnessed police strikes. A one standard deviation in police strikes increases the relative risk of beatings by 72 percent and burnings by 76 percent (Figure 4c). We cannot reject the null hypothesis of no association between police strikes and bombings $(\mathrm{p}=.39)$. The Egyptian regime's crackdown at Rabaa is 


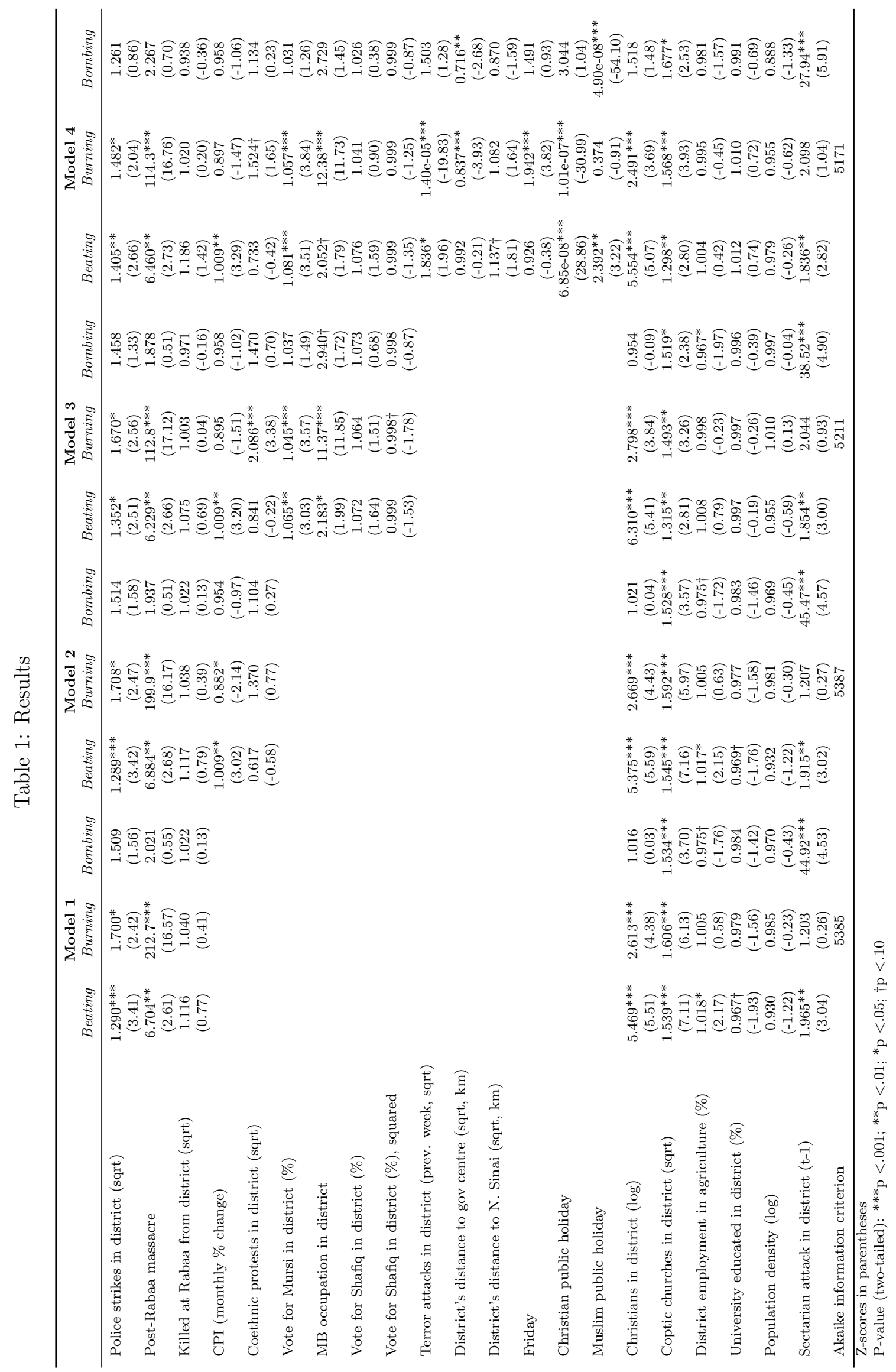


strongly correlated with two different types of ethnic violence. In the seven days following the massacre, districts were 6.4 times more likely to experience beatings, and 114 times more likely to suffer burnings. There is no statistically significant association between the immediate post-Rabaa period and bombings. Note that when comparing between event types, burning events were significantly more likely to occur in the aftermath of the Rabaa massacre than either beatings or bombings (both $\mathrm{p}<.01$ ). There is no robust association between ethnic violence of any type and the home districts of those killed at Rabaa.

Our variables testing the importance of associational and economic life receive mixed support, though they are most predictive of beatings. Beatings were more likely to occur following increases in the cost of living: a one standard deviation increase in CPI from the previous month is associated with an 11.8 percent increase in the risk of beatings (Figure 4d). By contrast, CPI is negatively associated with burnings and bombings, but the coefficients are not significant. Coethnic mobilization receives even less support. The occurrence of recent Muslim-Christian protests in a district is negatively associated with beatings, and positively associated with burning and bombings. However, none of these relationships are significant at $\mathrm{p}<.05$.

Explanations rooted in political organization and competition find partial support, but their importance depends on the event type. A one standard deviation increase in electoral support for ousted Islamist president Muhammad Morsi increases the risk of beatings and bombings twelvefold (both $\mathrm{p}<.001$; see Figure $4 \mathrm{e}$ ). By contrast, the incidence of bombings in a district is not significantly related to local electoral support for Morsi. Burnings were twelve times more likely to occur in districts where the Muslim Brotherhood had staged an anti-coup protest occupation $(\mathrm{p}<.001)$ - but there is no significant association between a Brotherhood occupation and the occurrence of beatings or bombings in a district. As theory predicts, there is a non-monotonic relationship between electoral support for the old regime candidate Ahmad Shafiq and the incidence of beatings, bombings, and burnings; however, these associations do not approach statistical significance at conventional levels. 

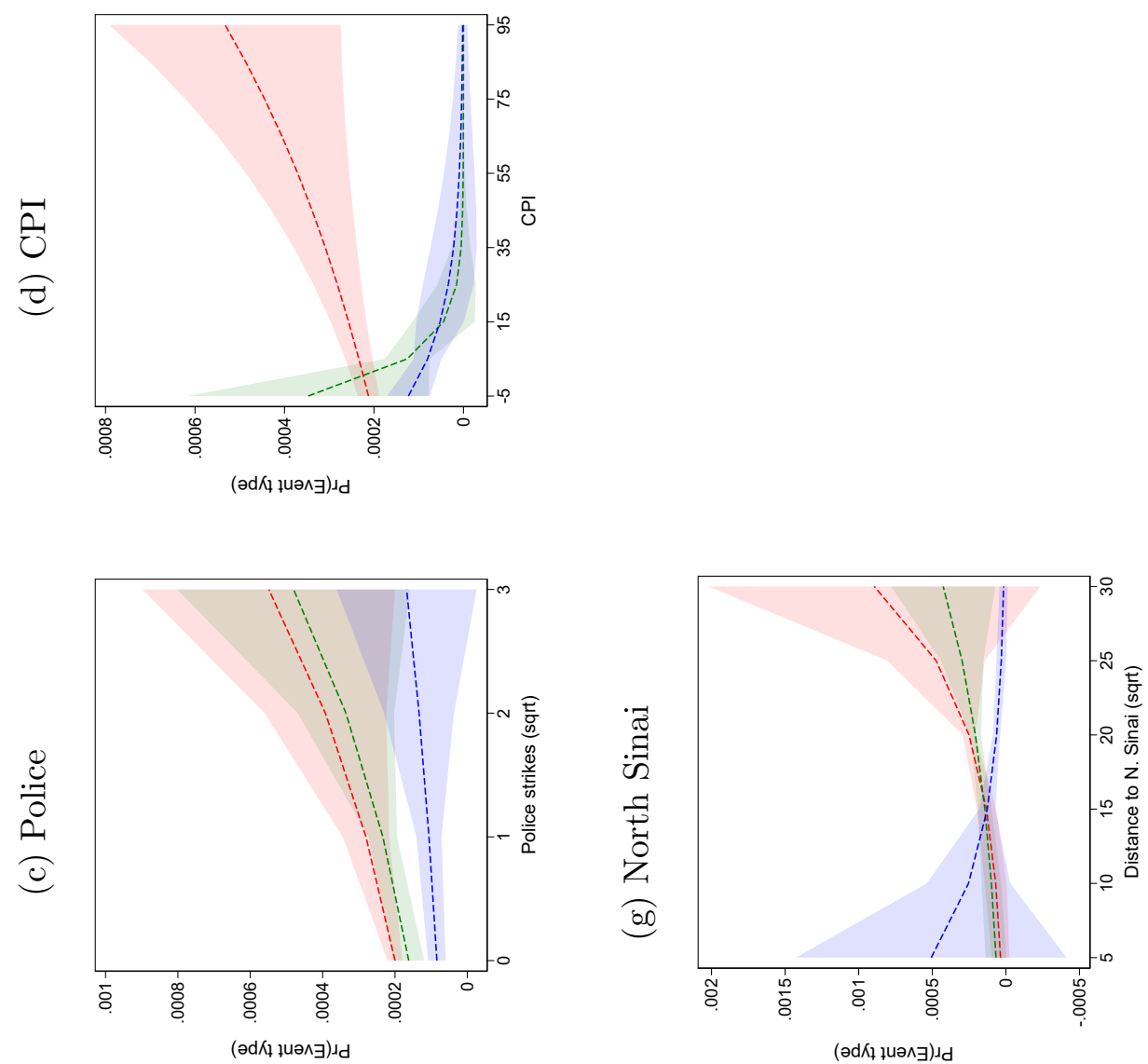

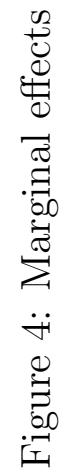
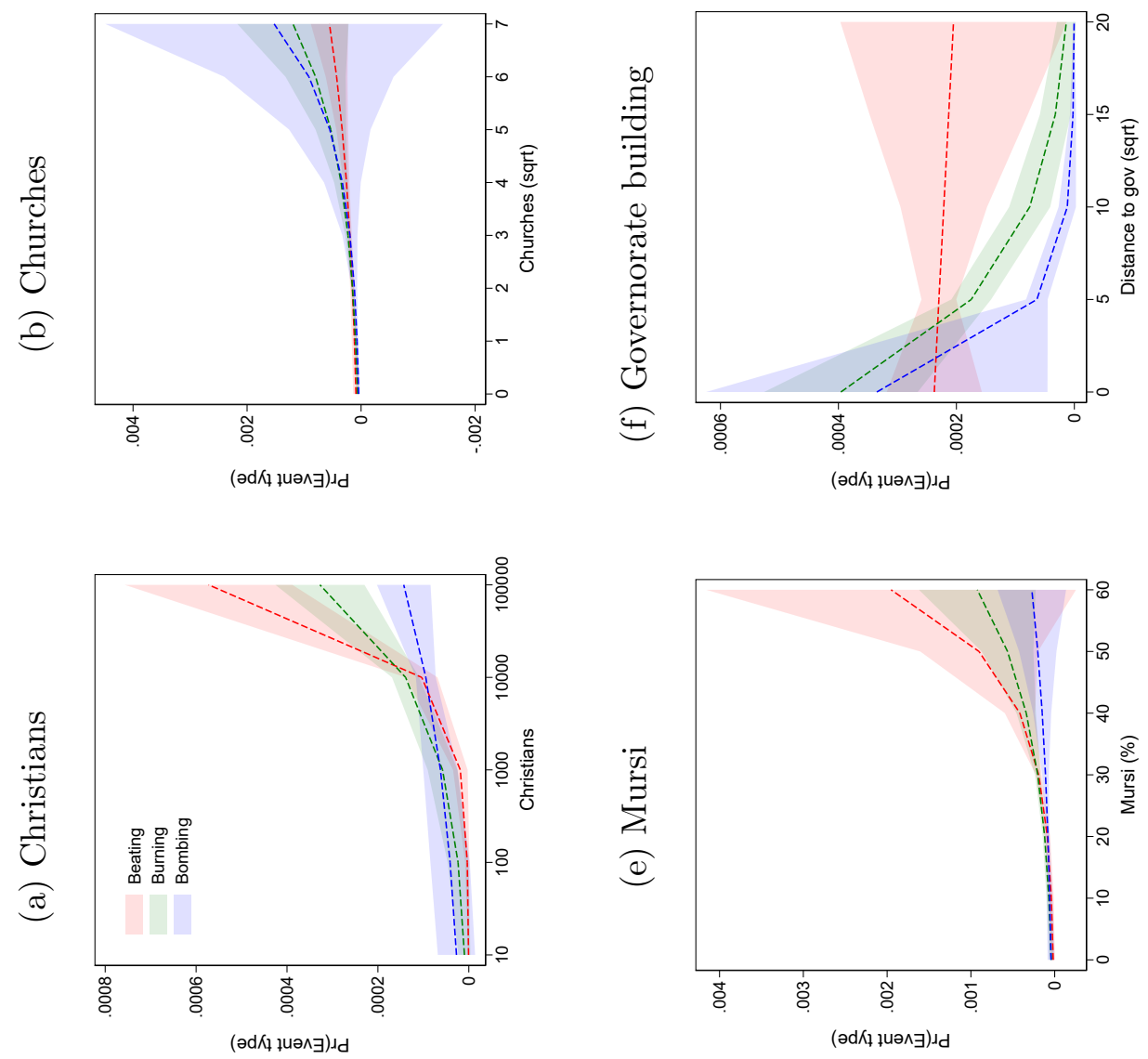

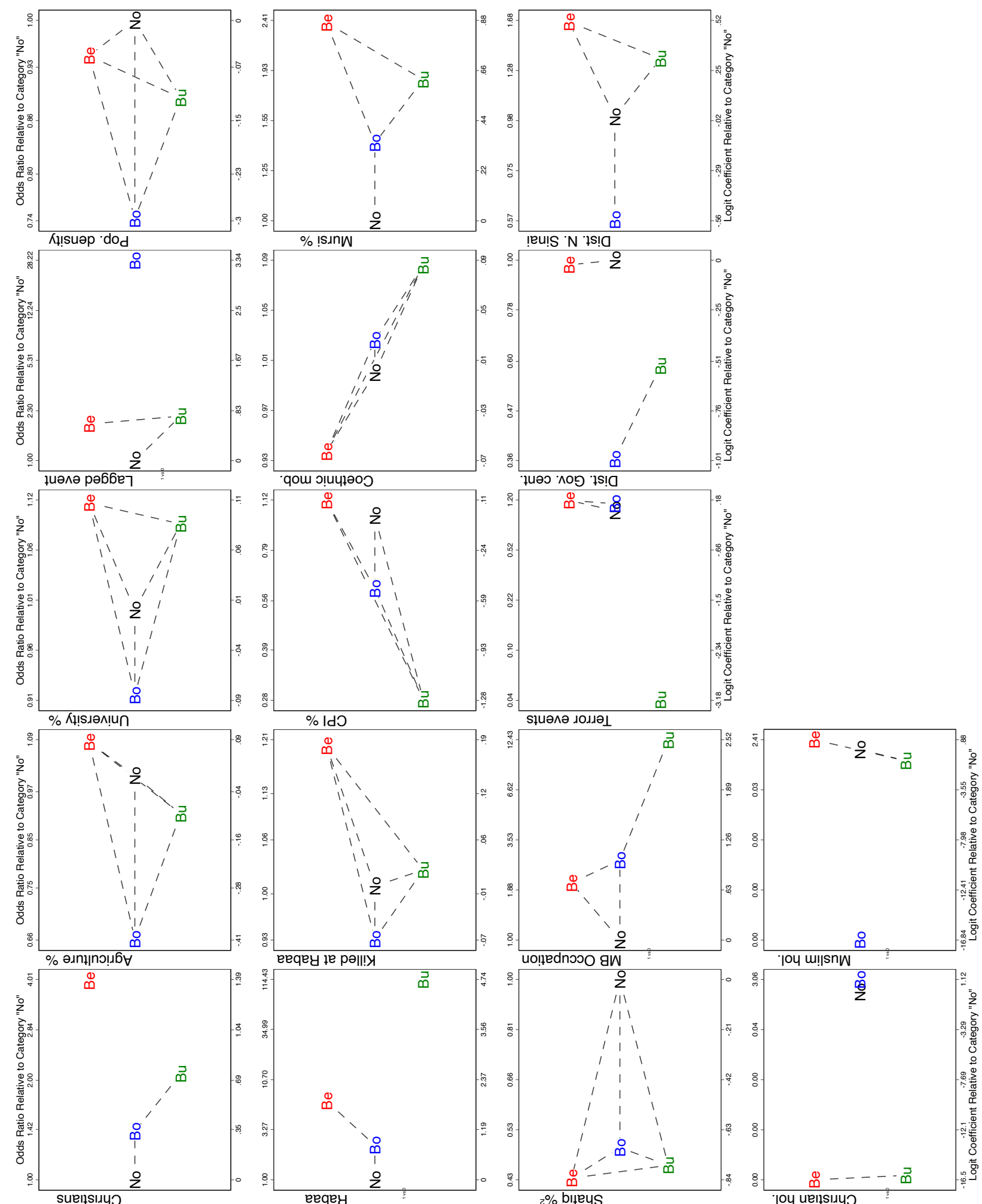

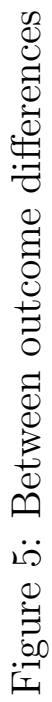
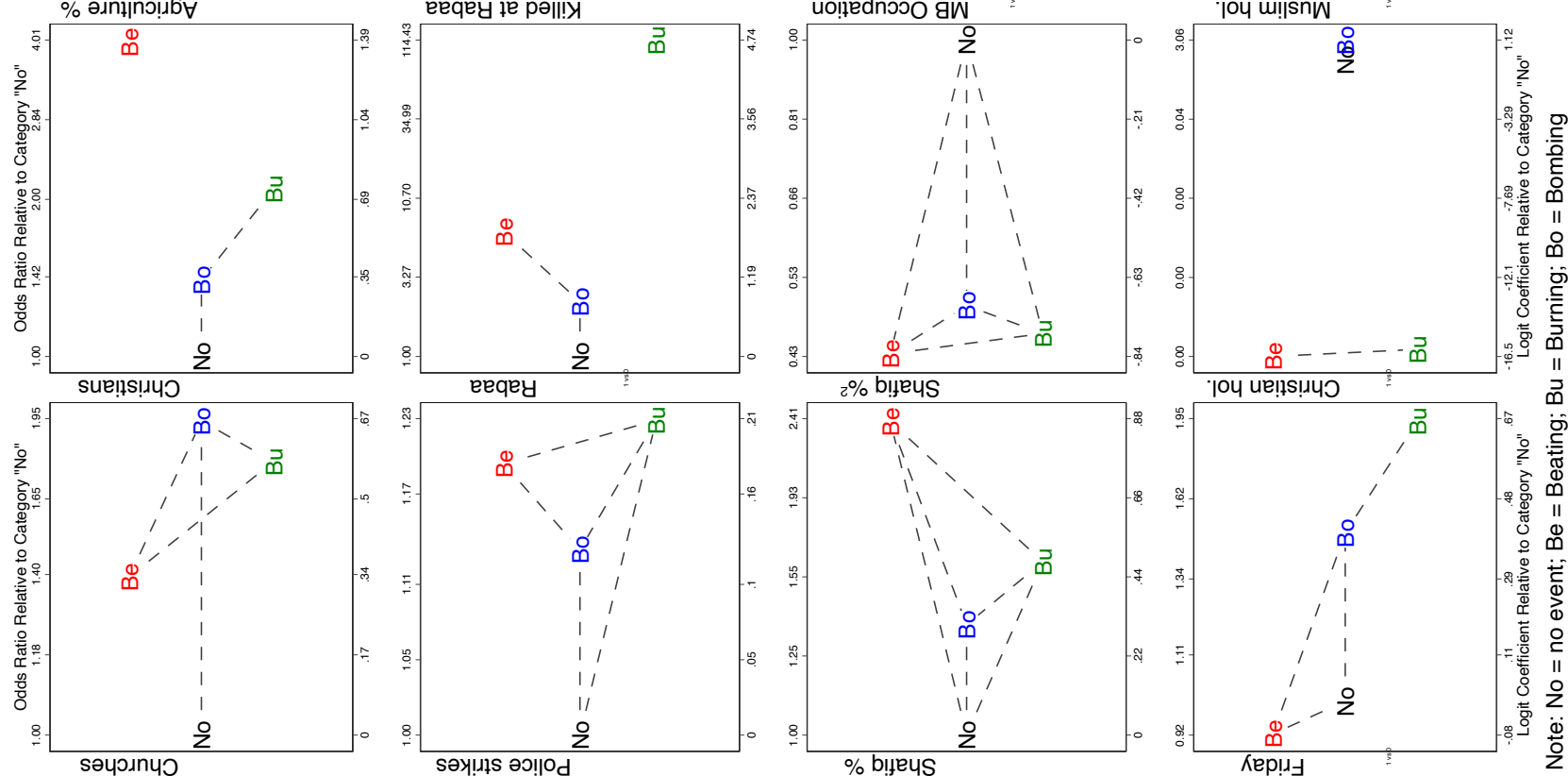
We now turn to the role of religious calendars and terrorist violence in patterning our three different categories of ethnic violence. Burnings were significantly less likely to occur following terror attacks, while the likelihood of beating events increased - and these differences are themselves statistically significant. The coefficient for bombings is positive, but again we cannot reject the null hypothesis of no association. The likelihood of both burnings and bombings declined with distance to governorate centers (Figure 4f). The association between beatings and proximity to political power is more ambiguous. Looking across categories, districts located closer to administrative centers were more likely to suffer burnings and bombings than beatings. The likelihood of beatings and burnings increases with distance from North Sinai, with the coefficient for burnings just statistically significant $(\mathrm{p}=.049)$. The incidence of terrorist violence appears to decline with distance from North Sinai (Figure 4g), although this association is not significant $(\mathrm{p}=.15)$. Comparing between event types, bombings were much more likely to occur in districts closer to North Sinai than either beatings or burnings. Burnings were 1.9 times more likely to occur on a Friday, compared to the base category. There is no significant association between Fridays and the incidence of beatings or bombings. The likelihood of beatings and burnings is significantly and substantively diminished on Christian holidays, while bombings increased - and this difference is also statistically significant. Finally, compared to the base category of no event, the likelihood of beating events increases during Muslim holidays, while there is a diminution in the incidence of bombings. Burnings were also less likely during these periods, although this association is not statistically significant. Again, comparing between categories, bombings were much less likely to occur on a Muslim holiday than either beatings or burnings.

\section{Discussion}

What is the overall picture that these results present? At the most general level, it is clear that while commonalities exist between our three violence types, there is also considerable variation in the underlying factors that predict their occurrence. Districts 
with large numbers of Egyptian Christians were especially vulnerable to unarmed violence against individuals; where minority groups exist in considerable numbers there is a greater likelihood of the kind of cultural and religious affronts that tend to provoke beatings. It appears that bombings are less obviously patterned by the distribution of the Christian population, suggesting that terrorist violence follows a more strategic logic, targeting Christian sites of symbolic importance regardless of whether Christians actually live nearby. We also found support for the claim that economic competition during downturns can be a trigger for violence, but because these attacks are fueled by parochial rivalries over scarce resources they tend to take the form of beatings. And we found that districts that experienced police strikes were more likely to witness both beatings and burnings. This dovetails with our qualitative description of events, which found that areas in which police forces had become professionally demoralized and/or hostile toward the Morsi government saw more violence because the police could or would not enforce order.

We also find considerable variation in the types of ethnic violence witnessed in the immediate aftermath of the Rabaa massacre. The ethnic backlash that followed this event was much more likely to take the form of burnings, whereby Muslims exacted collective punishment against Egypt's Coptic community for their perceived support of the military-backed coup. Underlining the importance of political mobilization and political entrepreneurs for this type of violence, we found that these burnings were much more likely in districts where the Muslim Brotherhood had recently organized a long-term sit-in. Again, this aligns with our qualitative analysis above, which revealed that many burnings during the Rabaa week were instigated by Morsi supporters marching from sitins in central city squares. In terms of electoral variables, we find that Morsi supporting electorates were more likely to be sites of beatings and burnings (but not bombings).

Districts closer to the symbolic center of the governorate were more likely to witness bombings, in line with the idea that terrorists stage these types of attacks to maximize their publicity and exposure before local and global audiences. We also find that burnings are more likely near governorate centers, which aligns with what we know about the 
pattern of attacks during the Rabaa week (i.e., starting in central urban squares and targeting major churches). Compared to beatings and burnings, bombings were also more likely to occur closer to North Sinai, where the terrorist group ABM was based.

We also find meaningful patterns in the timing of attacks relative to Christian and Muslim holidays. Christian holidays appear to be occasions of reduced violence when it comes to beatings and burnings. One interpretation of these results is that everyday Muslim citizens (but not terrorist groups) actively restrain themselves from attacking Christians on their days of worship, perhaps as a sign of respect for the sanctity of holy days. A complementary reading is that on these days Christians may simply be less vulnerable, due to congregating at religious sites where security has been enhanced. For Muslim holidays, we find that bombing events are significantly less likely while beating events are more likely. The first finding is in line with recent work on Islamist militancy, which finds that militants restrain themselves during Ramadan in anticipation of societal disapproval of violence during this holy month (Reese et al 2017). The increase in beatings during Muslim holidays may well be explained by the sensitivity of these periods and consequent increased likelihood that perceived affronts to religious or cultural mores (like Christians drinking or eating in public) trigger violence. Fridays are associated with an increase in burnings, suggesting that ritual congregation at the mosque provides the opportunity to engage in collective forms of violence, as it does other forms of collective action.

\section{Conclusions}

The preceding analyses have generated a number of important conclusions about the drivers of anti-Christian ethnic violence in Egypt over the years 2013 to 2018. The period under consideration is a complex one in Egypt's recent history; the country witnessed the return of military authoritarianism following a brief democratic experiment and the simultaneous rise of militant Islamism in its periphery. As we have shown, these broader political trends and dynamics shaped the types of ethnic violence that emerged in the 
country. First, for much of the period districts with large numbers of Christians faced relatively low-level but quite persistent attacks seeking retribution for a variety of perceived affronts over cultural or religious issues. Second, the watershed political moment of the 2013 coup and the subsequent Rabaa Massacre triggered a fierce wave of burning events that primarily targeted churches and other Christian properties in an effort to collectively punish the Christian community for their supposed support of the coup. And, third, as the Egyptian branch of the Islamic State grew stronger and more entrenched in the Sinai Peninsula it began to stage increasingly bloody attacks using guns, bombs, and other firearms against Egypt's Christian community, eventually declaring an all-out sectarian war at the end of 2016. Christians in Egypt have, in other words, been no strangers to violence during the period we examined; but the nature and drivers of the violence that afflicted them has varied considerably.

Beyond these important takeaways for the specific case of Egypt, we believe that our findings have broader implications for the way scholars of ethnic politics conceptualize and analyze patterns in violence. Using a typology based on the nature of the target and the level of violence, we have disaggregated ethnic attacks into three types - beatings, burnings, and bombings - and shown that the predictors of these three types of attacks are meaningfully distinct. The findings suggest that because the motivations for these attacks and the organizational capacity of the attackers are somewhat different, the causal processes that generate them may also be distinct and that attempts to come up with single, mono-causal explanations may fall short. Indeed, we have shown that some of the theories of ethnic violence that the literature has forwarded are well-suited to explaining certain types of attacks but not others: economic and religious factors seemed to affect beatings; political factors shaped the occurrence of burnings; measures of state capacity did a good job of explaining beatings and burnings; and variables capturing the strategic logic of terrorist organizations were best-suited to explaining bombings.

The disaggregation strategy we have proposed and applied in this paper provides one potential path forward for ethnic violence scholars faced with a range of conflicting findings or struggling to come up with effective universal theories. We believe our framework 
is helpful because it is both tractable, in that it can easily be applied to many datasets and cases, and conceptually meaningful, in that it captures important substantive differences in various forms of ethnic violence. Though we recognize that other disaggregation strategies may also be fruitful, we do believe that the typology we have proposed should be applied to other cases. This is not to say that our findings about the specific drivers of each type of violence would necessarily be the same in another case. Bombings, for example, could be driven not by a terrorist organization as in our case, but by another type of organized actor, like the state or organized political parties. In other words, even if the categorizations themselves should be applicable and meaningful in a broad range of cases, it remains an open question how many of our specific empirical findings will travel. Ultimately, whether scholars choose to adopt our framework or not, we hope that this paper has convincingly established the merit of disaggregating ethnic violence to better understand the underlying correlates of its different types. Ethnic violence incorporates myriad hostilities and takes multiple forms. Unpiecing this violence is a necessary first step to understanding how its constituent parts together form the whole. 


\section{$9 \quad$ References}

Al-Anani, Khalil. 2014. "ISIS Enters Egypt: How Washington Must Respond." Foreign Affairs, December 4.

Awad, Mokhtar and Mostafa Hashem. "Egypt's Escalating Islamist Insurgency." Carnegie Middle East Center.

Bormann, Nils-Christian, Lars-Erik Cederman, and Manuel Vogt. 2017. "Language, Religion, and Ethnic Civil War." Journal of Conflict Resolution 61 (3):744-771.

Brass, Paul R. 1997. Theft of an Idol: Text and Context in the Representation of Collective Violence. Princeton University Press.

Brownlee, Jason. 2013. "Violence Against Copts in Egypt." Washington: Carnegie Endowment for International Peace.

Brubaker, Rogers and David D. Laitin. 1998. "Ethnic and Nationalist Violence." Annual Review of Sociology 24:423-452.

Buhaug, Halvard, Cederman, Lars-Erik, and Jan Ketil Rød. 2008. "Disaggregating Ethno-Nationalist Civil Wars: A Dyadic Test of Exclusion Theory." International Organization 62:531-551.

Burt, Evan W. 2017. "The Sinai: Jihadism's Latest Frontline." The Wilson Center, September 13.

Byman, Daniel. 1998. "The Logic of Ethnic Terrorism." Studies in Conflict 68 Terrorism 21 (2): 149-69.

Capoccia, Giovanni, and Daniel Ziblatt. 2010. "The Historical Turn in Democratization Studies: A New Research Agenda for Europe and Beyond." Comparative Political Studies 43 (8-9): 931-68.

Cederman, Lars-Erik, Andreas Wimmer, and Brian Min. 2010. "Why Do Ethnic Groups Rebel?: New Data and Analysis." World Politics 62 (1): 87-119.

Chandra, Kanchan. 2006. "What Is Ethnic Identity and Does It Matter?" Annual Review of Political Science 9 (1): 397-424.

Clarke, Killian. 2011. "Saying 'Enough': Authoritarianism and Egypt's Kefaya Movement." Mobilization 16(4):397-416. 
Clarke, Killian. 2014. "Unexpected Brokers of Mobilization: Contingency and Networks in the 2011 Egyptian Uprising." Comparative Politics 46 (4): 379-97.

Clarke, Killian. 2017. "Social Forces and Regime Change: Beyond Class Analysis." World Politics 69 (3): 569-602.

Clarke, Killian. 2020. "Overthrowing Revolution: The Emergence and Success of Counterrevolution, 1900-2015." PhD Dissertation, Princeton University, Department of Politics.

Crenshaw, Martha. 1981. "The Causes of Terrorism." Comparative Politics 13 (4): 379-99.

Dancygier, Rafaela M. 2010. Immigration and Conflict in Europe. Cambridge: Cambridge University Press.

Dhattiwala, Raheel and Michael Biggs. 2012. "The Political Logic of Ethnic Violence: The Anti-Muslim Pogrom in Gujarat, 2002." Politics \& Society 40(4):483-516.

El-Ghobashy, Mona. 2011. "The Praxis of the Egyptian Revolution." Middle East Report 258.

Egyptian Initiative for Personal Rights. 2014. "The Weeks of Killing: State Violence, Communal Fighting, and Sectarian Attacks in the Summer of 2013." June.

Esteban, Joan and Debraj Ray. 2011. "A Model of Ethnic Conflict." Journal of the European Economic Association 9(3):496-521.

Fahmi, Georges. 2014. "The Coptic Church and Politics in Egypt." Carnegie Middle East Center.

Fearon, James D., and David D. Laitin. 1996. "Explaining Interethnic Cooperation." American Political Science Review 90 (4): 715-35.

Francisco, Ronald A. 2004. "After the Massacre: Mobilization in the Wake of Harsh Repression," Mobilization 9(2): 107-126.

Hardin, Russell. 1997. One for All: The Logic of Group Conflict. Princeton University Press.

Hassner, Ron E. 2011. "Sacred Time and Conflict Initiation." Security Studies 20(4): $491-520$. 
Horowitz, Donald L. 1985. Ethnic Groups in Conflict. Berkeley: University of California Press.

Horowitz, Donald L. 2001. The Deadly Ethnic Riot. Berkeley: University of California Press.

Human Rights Watch. 2014. "All According to Plan: The Rab'a Massacre and Mass Killings of Protesters in Egypt," August 12.

Jha, Saumitra. 2013. "Trade, Institutions, and Ethnic Tolerance: Evidence from South Asia." American Political Science Review 107(4):806-832.

Kadivar, Mohammad Ali, and Neil Ketchley. 2018. "Sticks, Stones, and Molotov Cocktails: Unarmed Collective Violence and Democratization." Socius 4 (January).

Kalyvas, Stathis N. 2006. The Logic of Violence in Civil War. Cambridge: Cambridge University Press.

Karapin, Roger. 2002. "Antiminority Riots in Unified Germany: Cultural Conflicts and Mischanneled Political Participation." Comparative Politics 34(2):147-167.

Kastellec, Jonathan P. and Eduardo L. Leoni. 2007. "Using Graphs Instead of Tables in Political Science." Perspectives on Politics 5(4): 755-771.

Ketchley, Neil. 2017. Egypt in a Time of Revolution. Cambridge: Cambridge University Press.

Ketchley, Neil and Michael Biggs. 2015. "Who actually died in Egypt's Rabaa Massacre." Washington Post Monkey Cage, August 14.

Kopstein, Jeffrey S. and Jason Wittenberg. 2011. "Deadly Communities: Local Political Milieus and the Persecution of Jews in Occupied Poland." Comparative Political Studies 44(3): 259-283.

Lieberman, Evan S., and Prerna Singh. 2012. "The Institutional Origins of Ethnic Violence." Comparative Politics 45 (1): 1-24.

McCormick, Gordon H. 2003. "Terrorist Decision Making." Annual Review of Political Science 6(1): 473-507.

Negus, Steve. N.d. "Anti-Christian Violence in Minya." Unpublished report.

Oliver, Pamela E. and Gregory M. Maney. 2000. "Political Processes and Local Newspa- 
per Coverage of Protest Events: From Selection Bias to Triadic Interactions." American Journal of Sociology 106(2): 463-505.

Olzak, Susan. 1992. The Dynamics of Ethnic Competition and Conflict. Stanford: Stanford University Press.

Petersen, Roger D. 2002. Understanding Ethnic Violence: Fear, Hatred, and Resentment in Twentieth-Century Eastern Europe. Cambridge: Cambridge University Press.

Reese, Michael J., Keven G. Ruby, and Robert A. Pape. 2017. "Days of Action or Restraint? How the Islamic Calendar Impacts Violence." American Political Science Review 111(3):439-459.

Rowe, Paul S. 2013. "Christian-Muslim Relations in Egypt in the Wake of the Arab Spring." Digest of Middle East Studies 22(2):262-275.

Sambanis, Nicholas. 2001. "Do Ethnic and Nonethnic Civil Wars Have the Same Causes?" The Journal of Conflict Resolution 45 (3): 259-82.

Sartori, Giovanni. 1970. "Concept Misformation in Comparative Politics." American Political Science Review 64 (4): 1033-53.

Sidel, John T. 2006. Riots, Pogroms, Jihad: Religious Violence in Indonesia. Ithaca, NY: Cornell University Press.

Snyder, David. 1978. "Collective Violence: A Research Agenda and Some Strategic Considerations." Journal of Conflict Resolution 22(3): 499-534.

Tadros, Mariz. 2013. "Copts Under Mursi: Defiance in the Face of Denial." MERIP 267.

Tezcür, Güneş Murat. 2016. "Ordinary People, Extraordinary Risks: Participation in an Ethnic Rebellion." American Political Science Review 110 (2): 247-64.

Toft, Monica Duffy. 2003. The Geography of Ethnic Violence: Identity, Interests, and the Indivisibility of Territory. Princeton University Press.

Toft, Monica Duffy, and Yuri M. Zhukov. 2015. "Islamists and Nationalists." American Political Science Review 109(2): 222-38.

Toha, Risa J. 2017. "Political Competition and Ethnic Riots in Democratic Transition: A Lesson from Indonesia." British Journal of Political Science 47 (3): 631-51. 
Tilly, Charles. 2003. The Politics of Collective Violence. Cambridge: Cambridge University Press.

Urdal, Henrik. 2008. "Population, Resources, and Political Violence: A Subnational Study of India, 1956-2002." Journal of Conflict Resolution 52(4):590-617.

Varshney, Ashutosh. 2001. "Ethnic Conflict and Civil Society India and Beyond." World Politics 53(3): 362-398.

Varshney, Ashutosh. 2003. Ethnic Conflict and Civic Life: Hindus and Muslims in India. Yale University Press.

Varshney, Ashutosh. 2005. "An Electoral Theory of Communal Riots?" Economic and Political Weekly 40 (39): 4219-4224

Vogt, Manuel. 2018. "Ethnic Stratification and the Equilibrium of Inequality: Ethnic Conflict in Postcolonial States." International Organization 72 (1): 105-37.

Wilkinson, Steven I. 2004. Votes and Violence: Electoral Competition and Ethnic Riots in India. Cambridge: Cambridge University Press. 